\title{
Liability of employers for third party harassment in the UK.
}

\author{
MIDDLEMISS, S.
}

2021 


\title{
Liability of employers for third party harassment in the UK?
}

\begin{abstract}
The \#metoo movement in dramatic form brought the issue of sexual harassment in the workplace to the fore in all sectors and industries in the United Kingdom. Organisations that are perceived or reported to be involved in inappropriate sexual conduct can incur legal liability, attract adverse publicity and may suffer financially. One aspect of this is the liability of employers for sexual harassment perpetrated towards their employees by a third party. A third-party refers to someone that an employee interacts with as part of their job but who is not employed by the same employer as them. This could include; customers, clients, business contacts, staff who are not employed directly by the employer e.g. agency workers or staff who work for them in a self-employed capacity such as independent contractors. Harassment by a third party can be just as devastating for a worker as harassment by a colleague. In this article the current legal liability of an employer for acts of harassment perpetrated by third parties against their staff will be considered. This involves analysis of the complicated legal position of victims of third -party harassment. Consideration of the legal treatment of this issue in other jurisdictions will be undertaken to help identify the best way to change the law to better protect victims of third party harassment in the $U K$.
\end{abstract}




\section{Introduction}

Third -party harassment will clearly be a significant concern to employers in many industries and in particular those situations in which workers come into regular contact with the public (e.g., retail, hospitality, healthcare and aviation). Unfortunately, there has been a lack of widespread research undertaken into third party harassment in the workplace in the UK although, there are some notable research surveys into this issue.

The first research survey [1] was titled sexual harassment in the workplace and was undertaken by the TUC in 2016. The subsequent report by them considered amongst other things the characteristics of the perpetrators of sexual harassment. They found in the survey that in 9 out of 10 cases the perpetrator of the harassment was a man. With respect to third party harassment they found that : 7\% of respondents reported the perpetrator was a customer or client (third party harassment), although the report notes there was some variation across sectors, e.g. $9 \%$ of women in medical and health services, and also by age, with younger women more likely to be harassed by a third party. [2] The TUC recently followed this up with a survey into young peoples' experiences of third -party harassment. [3] They surveyed over 1,300 young workers aged 18 to 34 who had been subject to some form of third-party harassment, abuse or violence. The results were not only surprising but alarming. They asked the respondents about their experience of reporting third-party harassment to their employer and if they had reported it the impact the behaviour had on them and their attitude to work. The researchers found that, of the young workers who reported the harassment, abuse or violence to their employer, over three-quarters ( 76 per cent) 
said nothing changed, or the situation got worse. Also, it became clear that being subjected to verbal abuse by third-parties was a very significant issue for young workers. They found that 85 per cent of the young workers polled had experienced some form of harassment, abuse or violence or verbal abuse from third-parties. (Middlemiss: 2015) Another, surprising discovery was the volume and frequency of third-party harassment for young workers. They found that 70 per cent of those who experienced verbal abuse from third-parties had been subjected to it three or more times. All workers whose job requires interaction with the public or third-parties in the course of their employment are by default at a higher risk of experiencing harassment, abuse or violence from third-parties. Some of the survey respondents reported certain factors about their job that further heightened the risk of harassment, abuse or violence from a third-party. These were working alone at night or in circumstance where alcohol is (or has been) consumed by third parties. The BBC undertook research in 2018 [4] which found that third-party sexual harassment was most likely to be experienced by those who are working on temporary contracts or agency workers. They also found it is particularly prevalent within the retail, care and hospitality industries. The research showed that $18 \%$ of respondents had been sexually harassed by clients or customers.

In its 2018 report entitled Turning the tables: Ending sexual harassment at work, the Equality and Human Rights Commission gathered evidence from around 1,000 individuals and employers. In the report the EHRC stated that around a quarter of those reporting harassment had reported that the perpetrator was a third party. [5]

The TUC issued guidance to its representatives in March 2019 with the title Tackling third-party abuse and harassment. [6]

What is clear from the results of these studies is that sexual harassment by third parties is a much more serious and widespread issue than first thought. Young people are particularly at risk of third 
party harassment and verbal harassment is a particular problem for them. It identified that there are certain factors which make harassment more likely. What follows is a review of the current legal rules that apply to third party harassment.

\section{Current legal position in the UK}

\section{Equality law}

The law of discrimination dealing with third party harassment before the introduction of the relevant harassment provisions in section 26 of the Equality Act 2010 (EA) was relatively clear. This was because of the EAT's decision in the case of Burton v De Vere Hotels. [7] The EAT allowed an appeal by two waitresses against the finding of an employment tribunal that they had not been directly discriminated against by their employer. They were subjected to racially offensive remarks by a person (Bernard Manning) working as a comedian at a private function in their employer's hotel but not employed by them and members of the audience. The hotel was held to be liable for the race discrimination suffered by the waitresses on the basis that it had been in a position to prevent the abuse and failed to do so. While the harassment provisions (under s26 of EA) were not in effect at this time, the EAT held that this did amount to direct discrimination against the waitresses. It was therefore the case that an employer could be liable for discriminatory remarks made to employees by a person not employed by them.

However, the House of Lords in Pearce v Governing Body of Mayfield Secondary School [8] disagreed and decided that the Burton case had been wrongly decided. The Law Lords were of the opinion that to render an employer liable for direct discrimination there must be a failure on their 
part which must in itself be an act of discrimination. So, the failure of the employer must subject the employee to less favourable treatment for one of the protected reasons. In Burton the discriminatory act of the employer would have been on the ground of race however, the law lords could not find evidence of racist behaviour on the part of the employer. Lord Nicholls said: "The hotel's failure to plan ahead properly [by for example ensuring that the waitresses did not have to work in the room occupied by the private function] may have fallen short of the standards required by good employment practice, but it was not racial discrimination. I consider the case [of Burton] was wrongly decided by the Employment Appeal Tribunal.” [9] This case was overruled, but it was subsequently held that the UK position on third party harassment did not properly reflect the extent of employers' obligations to protect their employees from harassment under the EU Equal Treatment Directive. [10] In Equal Opportunities Commission v Secretary of State for Trade and Industry [11] the High Court held that aspects of the Pearce decision were not compatible with an employer's obligations to protect its employees from harassment under the Equal Treatment Directive. It was an application for judicial review of the new implementation by the government of the Employment Equality (Sex Discrimination) Regulations SI 2005 No. 2467. It was alleged, and found, that they were incompatible with the Framework Directive, 2000/73/EC. This resulted in the Government amending the SDA 1975 to include third party liability for sex harassment. However, legislation relating to other protected characteristics were not amended. [12] This ultimately led to Parliament's enactment of specific statutory provisions on third party harassment. These provisions were included in section 40 of the Equality Act 2010 (EA) which stated that an employer could be liable when they knew that an employee had been harassed by a third party on at least two previous occasions and did not take reasonably practicable steps to prevent the harassment. Employers could escape liability where they could successfully argue that they did 
not know about and could not be reasonably expected to know about the harassment by a third party. Even if the employee complained about alleged harassment to their employer how could the employer be certain of the truth if the third party did not admit to the harassment? The provisions in the EA 2010 on third party harassment were the 3 strikes requirement were substantially unworkable in practice and repealed in 2013. There is as a result currently no express statutory provision extending liability to an employer for harassment of their employees by a third party. The Fawcett Society in their Sex Discrimination Law Review in 2018 asked the Government to reintroduce section 40. [13] According to its Chief Executive in 2019: [14] "we need to strengthen the law to better protect women from harassment from co-workers, clients or customers and we need a new duty on employers to prevent sexual harassment. They have to take responsibility for their own workplace culture. " [15]

The question is could an employer currently be at risk of facing successful legal claims by their workers for failing to prevent sexual or other forms of harassment carried out by a third party. The answer is that it is complicated but, probably not. As will be seen this is an unacceptable state of affairs to many commentators or stakeholders. Until recently it was considered that there was another potential route to liability for employers in this context under the standard provisions on harassment in section 26 of the EA 2010. Harassment under the EA 2010 is defined as unwanted conduct which is: related to a protected characteristic (including sex, but also covering sexual orientation, race, religion, disability, age and gender reassignment); and has the purpose or effect of violating the victim's dignity or creating an intimidating, hostile, degrading, humiliating or offensive environment for them.

It was thought that this meant employees could potentially bring a case for harassment against their employer on the basis that an employer's failure to prevent harassment by a third party is 
itself unwanted conduct related to a protected characteristic that has the required harassing effect. However, in the recent case of Unite the Union v Nailard [16] the Court of Appeal held that this type of action has a very high threshold namely, to prove that the employer needs to have a discriminatory motive for failing to take action in the face of complaints of third party harassment in order for them to be liable. The court also concluded that the availability of liability for third party harassment was a matter for Parliament and specific statutory provisions were needed to be enacted to cover this. Although the current legal position in the UK does not give employees rights against their employers where they are harassed by third parties in the course of their work it is unwise for employers to ignore the issue. Businesses with workers who come into contact with third parties have a difficult balancing act to follow. They need to make sure that their staff are protected and supported but, at the same time they often cannot fully control the actions of third parties.

\section{Indirect Discrimination}

An alternative to an action for harassment is an action for indirect discrimination for third party harassment. It is possible that a failure to respond to complaints or a particularly unfair or discriminatory way of dealing with complaints of third-party harassment could amount to indirect discrimination. This occurs when a provision, criterion or practice (PCP) [17] is applied in the same way for all workers or a group of workers but, it has the effect of putting workers sharing a protected characteristic at a particular disadvantage (e.g. where third party harassment is a particular issue in the workplace and the majority of workers interacting with third parties are women). It does not matter that the employer did not intend to disadvantage the workers. Also, there is a presumption in favour of women as harassment places women at a particular disadvantage in comparison to men. Statistics have consistently shown that women are more likely 
to be sexually harassed at work than men. If a PCP is applied and puts workers sharing a characteristic at a disadvantage then it will be unlawful unless the employer can justify it.

Here employers' have to prove that they have a legitimate aim in applying the PCP and that the PCP was a proportionate way to achieve that aim. In the case of third-party harassment this might be difficult to justify.

Disadvantage needs to be established but this is a very broad term and can take many different forms. So, the disadvantage could be not having a complaint of harassment adequately investigated or allowing someone to work with another person who is a third party and a known harasser.

While Sheffield City Council v Norouzi, [18] is a race discrimination case it is still particularly relevant here. The facts were that the claimant was employed by the council as a residential social worker at a residential home. One of the children at the home was often abusive and offensive towards members of staff. In the case of the claimant, who was of Iranian origin, the girl was regularly offensive to him on racial grounds. The claimant became increasingly upset by her behaviour, and eventually when he could stand it no more, he went off sick and did not subsequently return to work. The tribunal upheld the claimant's complaints of harassment contrary to s.3A of the Race Relations Act 1976 and indirect racial discrimination contrary to s.1(1A) of the Race Relations Act 1976, on the basis that the council had not done enough to protect him from the effects of the child's behaviour. The EAT upheld the tribunal's decision. They held that in relation to both the racial harassment case and the indirect discrimination case, the essential question was one of fact, namely, whether the council had done enough to protect the claimant against the effects of the child's behaviour. Accordingly, the EAT ruled that it had been open to the tribunal to uphold the claimant's complaints on the basis of the legal analysis set out. However, they commented that some workplaces may inevitably expose employees to a risk of harassment 
that cannot be easily eradicated and urged tribunals not to find employers too readily liable unless they can point to specific failings. So, in limited circumstances an employer could be liable for harassment or discrimination committed by its third-party contractors etc.

\section{Other legal remedies?}

\section{Constructive Dismissal}

Employees who have been subjected to harassment by a third party may be able to bring a claim against their employer for third party harassment in the form of an action for constructive dismissal. This could apply where for example an employee resigns in response to harassing behaviour of a third party and claims that the employer's failure to protect them from the harassment amounts to a breach of their contract. A contract of employment between an employer and employee always includes certain implied terms. One of the implied terms that is particularly relevant here is a duty placed on an employer that they will not act in a way which destroys the trust and confidence between them and the employee. In the leading case of Malik v BCCI SA, [19] the employee had his future job prospects materially damaged because of his employment and association with BCCI, a fraudulent bank. They had breached the term of trust and confidence in his contract. He claimed and was awarded stigma damages, which is a remedy that reflects extreme injury to reputation and is only available in England and Wales. The House of Lords decided in this case that the employee's contract contained an implied term that the bank would not, without reasonable and proper cause, conduct itself in a manner likely to destroy or seriously damage the relationship of confidence and trust between employer and employee. Obviously having an organisational culture of harassment, bullying or discrimination or failing to protect workers from intimidatory behaviour of which they are aware would represent a breach of the implied term. The House of Lords extended the duty of trust and confidence to include a positive 
obligation on the employer to take all steps which are necessary to achieve the purposes of the employment. This could extend to protecting fringe workers from harassment, bullying or discrimination by colleagues and third parties.

Another implied term, breach of which could underpin a claim of constructive dismissal, applies where an employee suffers physical or mental harm because an employer failed to provide a safe working environment that is free from third party harassment. Breach of this duty might arise where an employer fails to; respond to a harassment complaint or provide adequate supervision to monitor or control third party harassment. In Waltons \& Morse v. Dorrington [20] an employer that failed to operate a no-smoking policy was found to be acting in breach of an implied duty formulated by the Employment Appeal Tribunal namely, failing to provide and maintain a working environment which is reasonably suitable for the performance by their employees of their contractual duties. The scope of this term was summarised in the following quote. "The implied duty to provide a reasonably suitable working environment also can be regarded as encompassing a duty to protect the employee from violence or from harassment, whether sexual or racial, or in the form of general bullying."

Businesses might consider whether their commercial agreements (with clients, suppliers, and other third parties) should expressly prohibit unlawful harassment of their staff by third parties or their representatives and whether appropriate contractual remedies could be built into those agreements in the event of a breach. If an employer breaches one of these implied terms then the employee will be entitled to treat this as a repudiation of their contract and as a response resign and claim that they have been constructively dismissed. This would be an unfair dismissal which is contrary to section 95(1) (C) of the Employment Rights Act 1996. 


\section{Actions in tort}

Under the common law of tort an employer could also be liable for negligence if the employee suffered mental and/or physical injury because of harassment by a third party that the employer could reasonably have foreseen and prevented or reduced. Employers should ensure that they continue to take all reasonably practicable steps to prevent the harassment of employees. There are 3 aspects to this duty of care under the law of delict as set out by the House of Lords in the case of Caparo Industries plc v Dickman. [21] The first part relates to any harm an employee suffers. This harm must occur as a result of the action or inaction of the employer. The employer must also have been able to reasonably foresee the harm. This might be more difficult to establish in cases involving psychological harm. The second part deals with the relationship between a claimant and defendant in a duty of care legal case. The House of Lords judgement stated there must be proximity in this relationship. In other words, there must be a relationship such as that between an employer and employee. This proximity might not apply in the relationship between the victim and a third party. However, if what the third party does is an integral part of an employer's activities then the employer could be liable for harassment perpetrated by them against their employees. The third part concerns whether liability should apply. In the eyes of the law, there should be fair, just and reasonable cause to impose a duty of care on an employer. Employers owe a duty of care to protect employees from psychological harm which is caused by bullying or harassment. A workplace breach of duty may occur if an employer fails in their responsibilities, and an employee is injured at work as a result of this negligence. Assuming all three elements are present then this type of action could be successfully pursued. However, a disadvantage is it must be pursued through the courts. 
Civil claims in relation to third party harassment could be brought under the Protection from Harassment Act 1997 (PHA). However, there are some legal hurdles that need to be overcome if a claim is to be successful. The Act established that an individual can bring a claim against the perpetrator if he or she can establish they have been subjected to a course of conduct (more than one incident) which amounts to harassment and which his harasser knew or ought to have known amounted to harassment of them. Another limitation of the civil claim is that it only available as a remedy for conduct which amounts to behaviour that is sufficiently serious as to constitute a criminal offence under the Act. This requirement limits the applicability of the Act to only the most serious forms of harassment. The PHA does enable individuals to bring claims against thirdparty perpetrators but does not make the victim's employer liable for a third party's actions. In addition, PHA claims require proof of the state (or deemed state) of mind of the perpetrator, while Equality Act harassment claim doesn't depend on any consideration of knowledge or intention and so is easier to prove. PHA claims can be brought in the County or High Court which could mean that Legal Aid is available. The downside is the claimant could face an order for the perpetrator's costs if they are unsuccessful.

\section{Practical steps of employers to minimise their liability}

Irrespective of the risk of legal action being taken against them by employees, employers who do not help and protect their staff when they are faced with harassment by third parties risk significant damage to their reputation in the current climate. Allegations of mishandling the situation can as a result of the internet and social media quickly be made public, go viral and reach huge audiences. The mis-handling of an allegation of third-party harassment could therefore be harmful to a business's commercial standing and reputation. Employers who are perceived as not providing 
adequate protection and support to staff will not be regarded as an attractive place to work and they will struggle to retain staff. There are a number of steps that employers can take to safeguard their reputation and minimise the risk of successful legal actions. Firstly, it is important for employers to take steps to prevent or respond to complaints of third-party harassment not least because otherwise they may be liable under the Equality Act or other legislation or contract and tort law under the common law. Secondly, a minimum for employers is to have a sexual harassment policy providing workers with the means to raise complaints not only about co-workers but, also third parties. The policy should clearly state that harassment of staff by customers or other third parties will be taken seriously and appropriate action taken when complaints are made. The policy should be publicised to all staff and should be easily accessible. Thirdly all employees and third parties interacting with staff must know what behaviour is and what is not acceptable and it is fundamental for employers to educate them accordingly. Fourthly training for managers and HR personnel on how to handle complaints of harassment not only against co-workers but, also third parties is essential. Training should cover how harassment allegations should be investigated and what options might be available to sanction or pursue third parties who harass staff (e.g. if they are clients or customers they could be reported to the police by the employer or they can simply refuse to have dealings with them in the future). Also, training should cover how complainants should be treated. It is clear that simply having the policy is not enough and it is fundamental that those to whom allegations are likely to be made appreciate the importance of treating those complaints seriously and listening to complainants. 


\section{Legal treatment of the issue in other jurisdictions}

Two countries that are close neighbours to the UK have legislation on sexual harassment which covers third party harassment is France and Ireland. France has recently changed its law on sexual harassment and it is now broad enough to cover third party harassment. [22] The amended French Employment Code defines sexual harassment as 'repeated sexual comments or conduct that either violates the dignity of an employee because of its degrading or humiliating nature or creates an intimidating, hostile or offensive situation against the employee. It also includes the act of exerting any form of serious pressure, even if not repeated, for the real or apparent purpose of obtaining an act of a sexual nature, whether it is sought for the benefit of the perpetrator or for the benefit of a third party. More significantly the law no longer limits sexual harassment to hierarchical relationships such as that between an employee and their manager or between colleagues but, also includes relationships between an employee and a third person connected to the company e.g., a customer or supplier. Sexual harassment can also occur outside working time and away from the place of work (on a business trip, for example). The law in France is clearly broader in its coverage than the law in the UK currently in terms of the types of relationships covered and the scope of where the harassment is protected.

In Ireland the Employment Equality Acts 1998-2015 protect employees from employment-related sexual harassment. The Acts defines sexual harassment as any form of 'unwanted verbal, nonverbal or physical conduct of a sexual nature.' Similar to UK law harassment is defined as conduct which has the purpose or effect of violating a person's dignity and creating an intimidating, hostile, degrading, humiliating or offensive environment for the person and is prohibited under the Acts The harassment can be perpetrated by a colleague, an employer or someone in a superior position, a client, a customer or any other business contact. It can take place at work or on a training course, 
on a work trip, at a work social event or any other occasion in respect of which the employer ought reasonably to have taken steps to prevent it.

In both jurisdictions a single incident of harassment by a third party is sufficient to breach the law.

In the United States, which often has a more generous protection for victims of discrimination and harassment than the UK [23] Title VII of the Civil Rights Act of 1964 (as amended) prohibits all employment discrimination on the basis of sex at the federal level which includes sexual harassment by third parties. As well as this a number of states have local laws that also prohibit third party sexual harassment in the workplace. While the precise nature of the legal rules will vary across states several of them do provide more significant protection for employees than federal law. [24] The Federal regulations state explicitly that "an employer may . . .be held responsible for the acts of non-employees [under Title VII] where the employer (or its agents or supervisory employees) knows or should have known of the conduct and fails to take immediate and appropriate corrective action." [25] So liability will be limited to employers who know about the sexual harassment by a third party and are in a position to control such behaviour but, fail to do so. The US position under federal law is not far from the position in the UK under case law prior to the Equality Act 2010 and could represent a suitable compromise position for any future legal rules in the UK. [26]

\section{Recent developments}

The intense media focus on stories of sexual harassment in the wake of the Weinstein scandal and other high-profile cases has led to the current legal regime being scrutinised. The Equality and Human Rights Commission and the Women and Equalities Select Committee of the House of Commons have both repeatedly called for the third-party harassment provisions in the Equality 
Act 2010 to be reinstated. The Equality and Human Rights Commission (EHRC) published a paper in 2018 [27] which specifically recommended not only to reinstate the third party harassment provisions but, also to amend them to remove the requirement for the employer to know that the employee has been subjected to two or more instances of harassment before they become liable. The Women and Equalities Committee (WEC) has also held an inquiry into sexual harassment in the workplace and released their report in mid-July 2019. [28] One of the stated aims of the inquiry was to obtain evidence on how workers can be better protected from sexual harassment by clients, customers and other third parties. The report recommended that the reintroduction of a specific statutory provision making employers liable for failing to prevent third party harassment of workers. Similar to the EHRC the WEC recommended that this should not be limited to cases where the employer was aware of two previous occurrences of harassment. The WEC also recommended the introduction of a statutory duty on employers to prevent sexual harassment at work and punitive fines for those who do not comply. The stakes may therefore be raised significantly for employers who do not sufficiently protect their employees.

As a consequence of these reports there was a Government consultation which ran from 11 July to 2 October 2019 on whether new third-party harassment provisions should be introduced and, if so, when an employer should become liable. The consultation sought views on whether the reasonable steps defence should apply and whether an employer's constructive knowledge of the harassment would be sufficient for them to be liable. The outcome of this consultation is still awaited.

\section{Conclusion}


Employees often come into contact with third parties at work, such as customers, clients, service users, visitors and those who have a different employer e.g. agency workers, independent contractors. The survey carried out by the Equality and Human Rights Commission (EHRC) on harassment in the workplace found that just under a quarter of those who responded had been harassed by a customer, client or service user. [29] There are various legal options available outside the Equality Act however, they are all fraught with evidential difficulties which make it difficult to successfully pursue a case and may serve to dissuade potential litigants.

It will be interesting to see the outcome the Government's consultation on proposals to reintroduce third-party harassment provisions in the Equality Act 2010. There is clearly a need to reintroduce protection for workers from third party harassment under the Equality Act 2010. As has been shown the precise nature of the protection has been a matter of contention. While most people agree that the need to show that three incidents of third-party harassment have taken place and that the employer knew of the harassment before the employer could be liable was somewhat draconian. The vexed question is if you are going to reintroduce protection against third party harassment into the Equality Act 2010 what do you replace the original provisions with? The legal rules in the other European jurisdictions discussed both explicitly cover third party harassment within their legislation and treat it in the same way as harassment in the workplace with one incident of harassment being enough to incur liability for the employer. An option being considered under the consultation is placing a new legal duty on employers to take all reasonable steps to prevent sexual harassment. This is a similar approach to that adopted in the federal law of the US and it seems a suitable basis for liability to apply. The rationale for this new duty is that it would for the first time place a proactive duty on employers to take action before unlawful conduct has taken place. Another aspect of this is would an employer be required to have knowledge of 
third-party harassment or would it be enough to show that they ought to have known of it (constructive knowledge) before becoming liable. Again, in the US a knowledge of third party harassment occurring is a necessary element of a case against employers in this context. The reform process has been put on hold due to the slowdown of parliamentary business in the commons due to the coronavirus but hopefully it will be back on the agenda soon.

\section{References}

Middlemiss, S “Another nice mess you've gotten me into" employers' liability for workplace banter, (2017) International Journal of Law and Management, Vol. 59 Issue: 6, pp.916-938

\section{Notes}

[1\} In 2016, the TUC commissioned polling on experiences of workplace sexual harassment, using a sample of 1533 adult women in Great Britain who were happy to be asked about sexual harassment and had current or previous experience of being in paid work. This was followed by a TUC survey of union members in order to gather more qualitative data to complement the findings of the polling.

[2] TUC Still just a bit of banter? https://www.tuc.org.uk/sites/default/files/SexualHarassmentreport2016.pdf

[3] TUC Not part of the job: Young workers' experiences of third-party harassment: polling and survey findings 05/12/18 https://www.tuc.org.uk/research-analysis/reports/not-part-job

[4] BBC Sexual harassment in the workplace ComRes were commissioned by the BBC and they surveyed 6,206 British adults online aged 18+ between 15th November and 24th November 2017 https://www.comresglobal.com/wpcontent/uploads/2017/12/BBC-sexual-harassment_FINAL_v3.pdf

[5] Equality and Human Rights Commission (2018) Turning the tables: ending sexual harassment at work https://www.equalityhumanrights.com/en/publication-download/turning-tables-ending-sexualharassment-work

[6] https://www.tuc.org.uk/resource/tackling-third-party-abuse-and-harassment

[7] (1996) IRLR 596

[8] (2004) 1 All ER 339

[9] Paragraph 35 
[10] Council Directive 76/207/EEC of 9 February 1976 on the implementation of the principle of equal treatment for men and women as regards access to employment, vocational training and promotion, and working conditions (Equal Treatment Directive) as amended by the Equal Treatment Amendment Directive 2002/73/EC of 23 September 2002. Repealed from 15 August 2009 by the Equal Treatment Directive (Recast) (2006/54/EC), which came into force on 15 August 2008.

[11] (2007) IRLR 327

[12] A case in point is Sheffield City Council v Norouzi UKEAT/0497/10/RN where the claimant who was an Iranian, and a residential social worker at a home for troubled children claimed one of the children's behaviour was extremely challenging and there were a number of incidents when the claimant was on shift including mocking of his accent and saying that he should go back home. The employer failed to act appropriately when he complained and as a result he went on sick leave and issued claims of harassment and indirect discrimination under the Race Relations Act 1976. The ET found that the respondent had been on notice of the problems following a report and had not put in effective measures to prevent the behaviour and that the behaviour was harassment for which the respondent was liable given their inaction. On appeal the EAT agreed.

[13] https://www.fawcettsociety.org.uk/Handlers/Download.ashx?IDMF=1f3c13a4-2112-48db-9569-eadc6741f317

[14] Sam Smethers

[15] https://www.fawcettsociety.org.uk/news/employers-should-be-legally-liable-if-they-fail-to-protect-their-stafffrom-sexual-harassment-at-work

[16] (2018) EWCA Civ 1203

[17] Provision, criterion or 'practice can include: workplace policies; the way in which access to any benefit, service or facility is offered or provided, one-off decisions that adversely affect a particular sex and directions to do something in a particular way which has a discriminatory effect e.g. dress codes.

[18] [2011] UKEAT/0497/10

[19] (1997) IRLR 462

[20] (1997) IRLR 488

[21] (1990) 2 AC 605

[22] The purpose of the law dated 3rd August 2018 was to strengthen the fight against sexual and gender-based violence and reinforce employers' obligations to prevent sexual harassment

[23] E.g. sexual favouritism

[24] E.g. California and New York

[25] 29 C.F.R. $\S 1604.11$

[26] E.g. EAT’s approach in Burton v De Vere Hotels (1996) IRLR 596 
[27] EHRC Turning the tables, Ending sexual harassment at work, March 2018 https:/www.equalityhumanrights.com/en/publication-download/turning-tables-ending-sexual-harassment-work

[28] https:/www.parliament.uk/business/committees/committees-a-z/commons-select/women-and-equalitiescommittee/inquiries/parliament-2017/sexual-harassment-workplace-17-19/

[29] EHRC Turning the tables, Ending sexual harassment at work, March 2018 https://www.equalityhumanrights.com/en/publication-download/turning-tables-ending-sexual-harassment-work 